\title{
Occurrence of antigammaglobulins in effusion fluids of diverse aetiology
}

\author{
L. P. PARKER, C. W. SEWARD, AND C. K. OSTERLAND*† \\ From the Departments of Preventive Medicine and Medicine, Washington University School of Medicine, \\ St. Louis, Mo
}

Human antigammaglobulins have been detected in high frequency in non-rheumatoid arthritis pleural (Levine, Szanto, Grieble, Bach, and Anderson, 1968) and synovial (Huskisson, Hart, and Lacey, 1971) effusions. The agglutinators, termed rheumatoid factors, were found in a much higher frequency than the 1 to 5 per cent. range of positive serological tests reported for the general population (Bartfeld, 1969; Waller, 1969).

Human antigammaglobulins are a diverse group of antibodies. The precise stimulus to their production is often obscure. Some appear to arise spontaneously as in the ageing process, while others are related to disease states. Many varieties of human antiglobulins have been delineated in terms of differences in specificity for autologous, isologous, or heterologous gammaglobulins, and by differences in reactivity in agglutination inhibition experiments (Grubb, 1970; Milgrom, Dubinski and Wozniczko, 1956; Ropartz, Rivat, and Rivat, 1971; Osterland, Harboe, and Kunkel, 1963; Vaughan, 1963).

Rheumatoid factors (RF) are known to be antibodies (Kunkel, 1963). The antigammaglobulin activity is found in all three major Ig classes (Torrigiani and Roitt, 1967) although the agglutination tests measure mainly IgM RFs. RFs are reactive with both native (Allen and Kunkel, 1966; Normansell, 1970) and altered IgG (Henney, 1969), and have specificity mainly for the Fc portion of the molecule (Williams and Kunkel, 1965).

Some of the test systems routinely used for RF probably detect several kinds of agglutinating substances. Not all positive RF agglutination tests should be considered necessarily to define the same antibodies. In general, RF testing has quite a high sensitivity, with positive tests in more than 80 per cent. of adult RA patients.

The presence of agglutinators in non-RA effusions is unexpected and it reduces the usefulness of RF tests in aiding diagnosis on such fluids. In this investigation, we have repeated studies on agglutinating activities in matched sera and effusion fluids from RA and non-RA patients. Four different serological systems were used to determine whether or not differences in patterns of reactivity or specificity between RA and non-RA are detectable. Our findings are that RFpositive results can be obtained in the non-RA fluids, although the frequency of this finding was less than previously reported (Levine and others, 1968; Huskisson and others, 1971). A striking feature of our results was the high incidence of agglutinating activity in the fluids tested as detected by the test system using human red cells sensitized with a diagnostic anti-R $h$ antibody. Further studies indicate that this agglutinating activity is Milgrom-type anti-antibody (Seward, Parker, and Osterland, 1972).

\section{Methods}

Sera and effusions for study were obtained from patients at the Washington University Medical Center. The material was treated with 1 per cent. sodium azide, and stored sterile at $4^{\circ} \mathrm{C}$. Synovial fluid specimens were treated with hyaluronidase (Bland and Clark, 1963; Hannestad and Mellbye, 1967) and centrifuged to remove debris. Heat inactivation of complement at $56^{\circ} \mathrm{C}$. for 20 to $30 \mathrm{~min}$. was performed before testing (Klein, Valkenburg, van Zwet, and Lafeber, 1966; Cheng and Persellin, 1971).

Sera and effusions were examined by four RF agglutination test systems: two commercial latex tests (Hyland, Colab) using human (Hu-latex) and bovine (Bov-latex) gammaglobulin, respectively; the sensitized sheep cell test (SSC) (Rose, Ragan, Pearce, and Lipman, 1948; Anderson, Bentzon, Houba, and Krag, 1970); and the sensitized human (D) cell test (SDC) (Waller and Vaughan, 1956; Grubb and Laurell, 1956).

All tests were performed by the tube technique with doubling dilutions. Agglutination was graded 0 to $3+$, read by two observers, and an agglutination of 2 was used as a reliable and reproducible end-point. All samples, particularly the effusions, were begun at quite low dilutions, usually $1: 4$ or $1: 5$. 
Standardization of the four tests was accomplished by comparison to the WHO International Reference Preparation of Rheumatoid Arthritis Serum (Anderson and others (1970). In addition, a strongly reactive rheumatoid serum of our own was lyophilized, reconstituted, and compared to the WHO serum for use as the laboratory standard.

\section{Results}

73 examples of effusions and the matching sera occurring in seventy patients were studied. Table I lists the principal diagnoses of these patients with effusions. All patients classified as RA met the ARA criteria for definite RA. Other connective tissue diseases (CTD) and those without a definite diagnosis of RA were included in the non-RA, CTD category. Patients having, as a primary diagnosis, a disease other than CTD were included in the miscellaneous category.

Table I Classification of diagnoses of the study population

\section{Diagnosis}

No. of
patients

(1) Pleural fluids and matched sera

A. Rheumatoid arthritis (definite) (4)

*RA with rheumatoid pleural effusion

RA with pleural effusions of other aetiology

B. Non-RA, connective tissue disease (CTD) (2)

SLE, drug induced

Scleroderma

C. Miscellaneous (23)

Pneumonia

SBE

Carcinoma

Congestive heart failure

Uremia

Pancreatitis

(2) Synovial fluids and matched sera

A. Rheumatoid arthritis (definite) (10)

B. Non-RA, connective tissue disease

(CTD) (3)

SLE

Acute rheumatic fever

Arteritis

C. Miscellaneous (28)

Internal derangement of knee

Degenerative joint disease

Gout

Reiter's

Other

Total
1

3

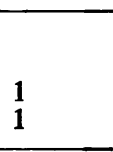

3

1

10

6

2

1

10

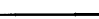

1

1

1

19

4

2

2

1
* Previously reported (Feagler, Sorenson, Rosenfeld, and Osterland (1971).
The WHO International Reference Preparation (IRP) of Rheumatoid Arthritis Serum was used to standardize both the four agglutination tests and a strongly reactive RA serum of our own, $M$; the latter serves as the laboratory control. The following reciprocal titres were obtained: IRP: Hyland ( $\mathrm{Hu}-$ latex)-128, Colab(Bov-latex)-64, SSC-64, SDC $64, ' M$ ' -1280 (in all four tests). By definition, the reference preparation in International Units (IU) contained 25 units per $\mathrm{ml}$. Therefore, each of the titres of the four tests was equivalent to 25 IU.

Table II represents the range of normal for the test systems in sera and effusions by reciprocal titre and IU. The sera and effusions represented 23 young adults with internal derangement of the knee (IDK) or degenerative joint disease (DJD) who were otherwise healthy. The values represent three standard deviations above the mean titre. Thus, values above this would have a probability of less than 1 per cent. of being normal.

Table II Upper limit of normal values for sera and synovial effusions

\begin{tabular}{|c|c|c|c|}
\hline \multicolumn{2}{|l|}{ Test } & \multirow{2}{*}{ 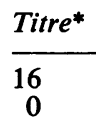 } & \multirow{2}{*}{$\frac{I U}{\begin{array}{c}3 \cdot 13 \\
0\end{array}}$} \\
\hline Hu-latex & $\begin{array}{l}\text { Serum } \\
\text { Fluid }\end{array}$ & & \\
\hline Bov-latex & $\begin{array}{l}\text { Serum } \\
\text { Fluid }\end{array}$ & $\begin{array}{l}8 \\
0\end{array}$ & $\begin{array}{c}3 \cdot 13 \\
0\end{array}$ \\
\hline$\overline{\text { SSC }}$ & $\begin{array}{l}\text { Serum } \\
\text { Fluid }\end{array}$ & $\begin{array}{l}32 \\
32\end{array}$ & $\begin{array}{l}12.5 \\
12.5\end{array}$ \\
\hline SDC & $\begin{array}{l}\text { Serum } \\
\text { Fluid }\end{array}$ & $\begin{array}{r}16 \\
8\end{array}$ & $\begin{array}{l}6 \cdot 2 \\
3 \cdot 1\end{array}$ \\
\hline
\end{tabular}

* Represents three standard deviations above a mean value.

Our decision was to continue recording reciprocal titres throughout the remainder of the paper in deference to convention, hopeful that in the future more extensive use will be made of the WHO International Reference Preparation and the international unit.

The occurrence of anti-IgG agglutinators in sera and synovial effusions is summarized in Table III (overleaf).

Only one abnormal test occurred in the miscellaneous effusion category; an SSC test with a reciprocal titre of 40 and no corresponding abnormal titre in the serum. Only one patient out of three with non-RA, CTD had abnormal tests in the serum, and none in synovial fluid. The highest titre was a latex $(\mathrm{Hu}-$ latex) of 160 . In contrast, nine of ten patients with definite RA had significant heterospecific anti-IgGs in both sera and synovial fluids (reciprocal titres 100 5,000 ). The tenth patient had only high titre SDC reactivity (sera-640, synovial fluid-80) in association with active polyarthritis; the other three tests 
Table III Occurrence of significant (abnormal) titres in sera and synovial effusions in 41 patients

\begin{tabular}{|c|c|c|c|c|c|c|c|c|c|c|c|}
\hline \multirow[t]{2}{*}{ Diagnosis } & \multirow{2}{*}{$\begin{array}{l}\text { No. of } \\
\text { patients }\end{array}$} & \multicolumn{4}{|c|}{ Serum } & \multirow{2}{*}{$\begin{array}{l}\text { No. of patients } \\
\text { with positive } \\
\text { result }\end{array}$} & \multicolumn{4}{|c|}{ Synovial fluid } & \multirow{2}{*}{$\begin{array}{l}\text { No. of patients } \\
\text { with positive } \\
\text { result }\end{array}$} \\
\hline & & $\bar{H}$ & $B$ & $S S C$ & $\overline{S D C}$ & & $\bar{H}$ & $B$ & $S S C$ & $\overline{S D C}$ & \\
\hline (1) $\mathrm{RA}$ & 10 & 9 & 9 & 9 & 10 & 10 & 8 & 9 & 9 & 12 & 10 \\
\hline (2) Non-RA, CTD & 3 & 1 & 1 & 1 & 1 & 1 & 0 & 0 & 0 & 0 & 0 \\
\hline $\begin{array}{l}\text { (3) Miscellaneous } \\
\text { *IDK, DJD } \\
\text { Gout } \\
\text { Reiter's syndrome } \\
\text { Other }\end{array}$ & $\begin{array}{r}23 \\
2 \\
2 \\
1\end{array}$ & $\begin{array}{l}0 \\
0 \\
0 \\
0\end{array}$ & $\begin{array}{l}0 \\
0 \\
0 \\
0\end{array}$ & $\begin{array}{l}\mathbf{0} \\
\mathbf{0} \\
\mathbf{0} \\
\mathbf{0}\end{array}$ & $\begin{array}{l}\mathbf{0} \\
\mathbf{0} \\
\mathbf{0} \\
\mathbf{0}\end{array}$ & $\begin{array}{l}\mathbf{0} \\
0 \\
0 \\
0\end{array}$ & $\begin{array}{l}0 \\
0 \\
0 \\
0\end{array}$ & $\begin{array}{l}0 \\
0 \\
0 \\
0\end{array}$ & $\begin{array}{l}\mathbf{1} \\
\mathbf{0} \\
\mathbf{0} \\
\mathbf{0}\end{array}$ & $\begin{array}{l}\mathbf{0} \\
\mathbf{0} \\
\mathbf{0} \\
\mathbf{0}\end{array}$ & $\begin{array}{l}1 \\
0 \\
0 \\
0\end{array}$ \\
\hline
\end{tabular}

* IDK = Internal derangement of the knee.

DJD $=$ Degenerative joint disease.

Table IV Occurrence of significant (abnormal) titres in sera and pleural effusions in 23 patients

\begin{tabular}{|c|c|c|c|c|c|c|c|c|c|c|c|}
\hline \multirow[t]{2}{*}{ Diagnosis } & \multirow{2}{*}{$\begin{array}{l}\text { No. of } \\
\text { patients }\end{array}$} & \multicolumn{4}{|c|}{ Serum } & \multirow{2}{*}{$\begin{array}{l}\text { No. of patients } \\
\text { with positive test }\end{array}$} & \multicolumn{4}{|c|}{ Effusions } & \multirow{2}{*}{$\begin{array}{l}\text { No. of patients } \\
\text { with positive test }\end{array}$} \\
\hline & & $\bar{H}$ & $B$ & $S S C$ & $\overline{S D C}$ & & $\bar{H}$ & $B$ & $S S C$ & $\overline{S D C}$ & \\
\hline (1) $\mathrm{RA}$ & $\begin{array}{l}3 \\
1^{*}\end{array}$ & $\begin{array}{l}3 \\
1\end{array}$ & 2 & 3 & $\underline{3}$ & & $\begin{array}{l}2 \\
1\end{array}$ & 1 & 2 & 1 & - \\
\hline Total & 4 & 4 & 2 & 3 & 3 & 4 & 3 & 1 & 2 & 1 & 4 \\
\hline (2) Non-RA, CTD & 2 & $\overline{1}$ & 1 & 0 & 1 & 1 & $\overline{1}$ & 1 & 0 & 1 & 2 \\
\hline $\begin{array}{l}\text { (3) Miscellaneous } \\
\text { Carcinoma } \\
\text { Congestive H.F. } \\
\text { Uremia } \\
\text { Pancreatitis } \\
\text { Infection } \\
\text { Other }\end{array}$ & $\begin{array}{r}10 \\
6 \\
2 \\
1 \\
3 \\
1\end{array}$ & $\begin{array}{l}1 \\
1 \\
1 \\
0 \\
0 \\
0\end{array}$ & $\begin{array}{l}0 \\
0 \\
0 \\
0 \\
1 \\
0\end{array}$ & $\begin{array}{l}0 \\
1 \\
0 \\
0 \\
0 \\
0\end{array}$ & $\begin{array}{l}3 \\
3 \\
0 \\
1 \\
3 \\
0\end{array}$ & $\begin{array}{l}3 \\
3 \\
1 \\
1 \\
1 \\
3 \\
0\end{array}$ & $\begin{array}{l}1 \\
0 \\
0 \\
0 \\
0 \\
1\end{array}$ & $\begin{array}{l}0 \\
0 \\
0 \\
0 \\
0 \\
0\end{array}$ & $\begin{array}{l}0 \\
0 \\
0 \\
0 \\
0 \\
0\end{array}$ & $\begin{array}{l}1 \\
1 \\
0 \\
0 \\
2 \\
0\end{array}$ & $\begin{array}{l}1 \\
1 \\
0 \\
0 \\
2 \\
1\end{array}$ \\
\hline Total & $\overline{23}$ & 3 & 1 & 1 & 10 & 11 & 2 & 0 & 0 & 4 & 5 \\
\hline
\end{tabular}

* Previously reported (Feagler and others, 1971) (B, SSC, SDC not performed).

were normal. As a generalization, all patients had higher titres in serum than in synovial fluid; although there was one instance in which the reciprocal SDC titre was 5,120 in synovial fluid and 1,280 in serum.

The occurrence of antigammaglobulins in paired sera and pleural effusions is summarized in Table IV. The miscellaneous group contained eleven patients with significant titres of agglutinators in the serum. However, only five had detectable titres in pleural fluid. The important observation is that only two of the 23 pleural fluids in this category contained reactivity detected by easily available systems (the two latex and the SSC tests); both reacted with human IgG coated on latex, and were of low titres $(1: 32$, $1: 40$ ). In addition, neither had concomitant reactivity in serum.

It was observed that the miscellaneous group of sera and fluids (Table V) frequently gave positive
Table V Tabulation of SDC testing in ten cases of non-rheumatoid pleural effusion

\begin{tabular}{|c|c|c|c|}
\hline \multirow[t]{2}{*}{ Diagnosis } & \multirow[t]{2}{*}{$\begin{array}{l}\text { No. of } \\
\text { patients }\end{array}$} & \multicolumn{2}{|c|}{$\begin{array}{l}\text { Reciprocal SDC } \\
\text { titre }\end{array}$} \\
\hline & & Serum & Effusion \\
\hline (1) Carcinoma & 3 & $\begin{array}{l}64 \\
40 \\
80\end{array}$ & $\begin{array}{l}32 \\
10 \\
10\end{array}$ \\
\hline (2) Infection & 3 & $\begin{array}{l}512 \\
640 \\
160\end{array}$ & $\begin{array}{r}64 \\
80 \\
0\end{array}$ \\
\hline $\begin{array}{l}\text { (3) Congestive heart } \\
\text { failure }\end{array}$ & 3 & $\begin{array}{l}256 \\
256 \\
160\end{array}$ & $\begin{array}{r}32 \\
0 \\
10\end{array}$ \\
\hline (4) Pancreatitis & 1 & 80 & 0 \\
\hline
\end{tabular}


titres in the SDC test system; ten in sera ( 43 per cent.), significant at $P<0.005$ ) and four out of the ten in pleural fluids (18 per cent.). In all examples of SDC agglutination in these pleural fluids, there was an equal or higher titre in sera. No examples of agglutination in pleural fluids in this group in conjunction with lower or negative serum titres were found. Of the two examples of low titre $\mathrm{Hu}$-latex agglutinators in pleural fluids in this group, one had SDC reactivity and the other did not.

In contrast, the patients with connective tissue disease, and RA in particular, were found to have a heterospecific group of agglutinators in both serum and pleural fluid as indicated by results of the four tests. In all instances, titres in serum were equal to, or in the majority, greater than ones in pleural fluids.

During preliminary testing of synovial fluids for agglutinations, it was observed that variable results were obtained. Agglutinations in the four test systems were often difficult to interpret, particularly with regard to end-point. Viscous fluids enhanced the agglutination problem. Synovial fluids were shown to clump uncoated latex particles of equivalent size and concentration to that used in RF testing, an effect not observed with pleural fluids. Serum and synovial fluid specimens from the ten patients with definite RA and an equal number of non-RA patients were examined in all four RF test systems before and after incubation for 15 minutes (at $37^{\circ} \mathrm{C}$.) with equal volumes of hyaluronidase $(3,5$, and $10 \mathrm{mg}$.) in phosphate-buffered saline (pH 7.0). In later work, 2 to 3 drops of hyaluronidase $(10 \mathrm{mg}$. $/ \mathrm{ml}$.) per $\mathrm{ml}$. synovial fluid was used before testing. Exposure of rheumatoid sera and fluids to hyaluronidase did not decrease the titres. Hyaluronidase-treated synovial fluids did not clump uncoated latex particles. NonRA synovial fluids that clumped uncoated latex particles and also gave low titre or borderline positive latex agglutination tests were generally reduced to normal values when incubated at $56^{\circ} \mathrm{C}$. for 20 to 30 min. Reduced viscosity improved endpoint determinations.

\section{Discussion}

The results of our search for anti-IgG agglutinators in sera and matched effusions of different aetiologies by three commonly used tests (Hu-latex, Bov-latex, SSC) indicate that they are uncommon in any significant titre in non-connective tissue diseases. The synovial effusions contained only one SSC titre of low but significant range. These results contrast with those of Huskisson and others (1971), who reported 37 per cent. positive SSC tests and 26 per cent. positive latex tests in a group of non-rheumatoid synovial fluids. Furthermore, they recorded twelve of eighteen patients with osteoarthroses, two of ten with traumatic arthritis, one with Reiter's disease, and one of three with gout with significant Waaler-Rose titres in synovial fluid.

There are significant differences in methods used in this study and that of Huskisson and others (1971). The latter study was carried out in a retrospective manner, whereas samples were collected prospectively for this study. Methodology differed for both the SSC and latex tests. The WHO requirements for the SSC test include a standard source of amboceptor (the British reference preparation), the tube-dilution technique, use of tube dilutions in determination of quantity of amboceptor necessary for sensitization of cells, and standardization of the test with the WHO International Reference Preparation (IRP) of RA serum.

In our examination of pleural effusions and paired sera in several non-connective tissue diseases (listed as Miscellaneous, Table IV), it was unusual to detect anti-IgG agglutinators by latex or SSC testing; 7 per cent. had a significant but low titre in sera, 2.6 per cent. had a significant but low titre in pleural fluid. The results contrast with those of Levine and others (1968) who reported that effusions from 41 per cent. of patients with bacterial pneumonia and 20 per cent. of patients with carcinoma contained significant titres of RF by their latex-agglutination method. They also noted four instances (in 65 examples) in which pleural fluid titres were significantly higher than serum values.

It is significant that they did not contrast the incidence of detection of anti-IgG agglutinators in a control population by their test techniques. They used both slide and tube-dilution methods; the slide test appeared more sensitive in detecting agglutination in pleural fluids. However, the fluids were not apparently heat-decomplemented before testing.

The heterospecificity of reactivity of RFs for human and other animal gammaglobulins observed in RA sera appears to be based on the existence of separate molecules with differing specificity (Milgrom and Tönder, 1965). Our current observations on RA support these conclusions. The fourteen RA sera studied showed classic RF heterospecificity in agglutination with human and at least one other species (bovine or rabbit) of IgG. The corresponding effusions contained one positive test and 75 per cent. contained at least three significant tests. The activity of these sera or effusions was markedly inhibited by human IgG in either the native or aggregated state.

Other anti-IgGs of more selective reactivity are also detectable by one or more of the agglutination tests used. The ten examples of significant SDC titres in Table V have been studied and shown to be antiantibodies (Seward and Osterland, 1973); that is, they were not inhibited by human IgG. Other characteristics for anti-antibody demonstrated were: stability during heating at $56^{\circ} \mathrm{C}$. for 2 hrs (RFs show significant decline in activity), narrow range of $\mathrm{pH}$ dependence of $7 \cdot 7$ to $7 \cdot 9$, and reactivity with the FC 
portion of the IgG molecule (Seward, Parker, and Osterland, 1974; Harboe, Rau, and Aho, 1965). Curiously, anti-antibodies are in general not found in association with RA (Grubb, 1970) but with other diseases, as supported by the present study.

In addition to specific antibody-antigen reactions in the tests used, non-specificity may be present. Incubation of synovial fluids in the presence of hyaluronidase eliminated non-specific agglutination of gammaglobulin-coated or uncoated latex particles, and by reducing viscosity greatly improved the readability of the agglutination test. Hyaluronidase has variously been reported to produce no significant effect on the SSC or latex test in both CTD and non-CTD (Bland and Clark, 1963), or to produce a favourable effect on the performance of a SSC test with, in several instances, conversion of a normal titre to a higher abnormal one (Krehl, Boisvert, deForest, and Mucci, 1957). We did not observe the latter effect of increased titres of agglutination. In other instances, in both serum and effusions, agglutination of gammaglobulin-coated latex particles of low titre was shown to be reduced by one or more tube-dilutions by incubation for $30 \mathrm{~min}$. at $56^{\circ} \mathrm{C}$. This agglutination has been considered to be a function of complement, specifically Clq (Cheng and Persellin, 1971).

\section{Summary}

The results of the present study suggest that, when multiple systems are used to detect RF, the patterns of anti-IgG reactions may be important. RFs of RA patients are heterospecific with regard to reactivity with human and other species of IgG, and are capable of being inhibited by native or aggregated IgG. Antibodies to human IgG of more restricted reactivity were demonstrated in the non-rheumatoid population. Anti-antibody was demonstrated as an isolated agglutinator in high frequency particularly in pleural effusions and matched sera. Other random agglutinators in low titre were detected in non-RA sera and fluids. Hyaluronates and complement produce nonspecific agglutinations, and means to avoid these difficulties were used. Our conclusion is that several test systems should be used for maximum specificity in testing for rheumatoid factor in effusions. When patterns of reactivity and agglutination inhibition are employed, it may be possible to distinguish RA and non-RA fluids.

\section{References}

Allen, J. C., AND KUnKel, H. G. (1966) Arthr. and Rheum., 9, 758 (Hidden rheumatoid factors with specificity for native gammaglobulins)

Anderson, S. G., Bentzon, M. W., Houba, V., And Krag, P. (1970) Bull. Wld Hlth Org., 42, 311 (International reference preparation of rheumatoid arthritis serum)

BARTfeld, H. (1969) Ann. N.Y. Acad. Sci., 168, 30 (Distribution of rheumatoid factor activity in nonrheumatoid states)

Bland, J. H., AND Clark, L. (1963) Yale J. Biol. Med., 36, 135 (Effect of hyaluronidase on sheep cell agglutination and latex fixation tests in contemporary sera and joint fluids)

Cheng, C. T., and Persellin, R. H. (1971) Ann. intern. Med., 75, 683 (Interference by Clq in slide latex tests for rheumatoid factor)

Feagler, J. R., Sorenson, G. D., Rosenfeld, M. G., ANd Osterland, C. K. (1971) Arch. Path., 92, 257 (Rheumatoid pleural effusion)

GruBB, R. (1970) 'The Genetic Markers of Human Immunoglobulins, p. 37. Springer, New York.

GRUBB, R., AND LAURELl, A. B. (1956) Acta path. microbiol. scand., 39, 390 (Hereditary serological human serum groups)

Hannestad, K., AND Mellbye, O. J. (1967) Clin. exp. Immunol., 2, 501 (Rheumatoid factor in synovial effusions: local production and consumption)

HARBOE, M., RAU, B., AND AHO, K. (1965) J. exp. Med., 121, 503 (Properties of various anti-gammaglobulin factors in human sera)

HeNNEY, C. S. (1969) Ann. N.Y. Acad. Sci., 168, 52 (Structural and conformational specificity of the antigen for rheumatoid factor)

Huskisson, E. C., Hart, F. Dudley, and Lacey, B. W. (1971) Ann. rheum. Dis., 30, 67 (Synovial fluid Waaler-Rose and latex tests)

Klein, F., Valkenburg, H. A., van Zwet, T. L., ANd Lafeber, G. J. M. (1966) Immunology, 10, 87 (Characterization of two different agglutinators in the latex fixation test, occurring in normal human sera)

Krehl, W. A., Boisvert, P. L., DeForest, G. K., AND Mucci, M. B. (1957) Yale J. Biol. Med., 30, 30 (The rheumatoid factor in serum and synovial fluid)

KunKel, H. G. (1963) Arthr. and Rheum., 6, 414 (The structure of rheumatoid factors)

Levine, H., Szanto, M., Grieble, H. G., Bach, G. L., AND ANDERSON, T. O. (1968) Ann. intern. Med., 69, 487 (Rheumatoid factors in nonrheumatoid pleural effusions.)

Milgrom, F., Dubinski, S., AND Wozniczko, G. (1956) Vox Sang., 1, 172 (Human sera with anti-antibody)

AND TÖNDER, O. (1965) Arthr. and Rheum., 8, 203 (Multiplicity of rheumatoid factor) 
NoRmansell, D. E. (1970) Immunochemistry, 7, 787 (Anti-gammaglobulins in rheumatoid arthritis sera. I. Studies on the $22 \mathrm{~S}$ complex)

Osterland, C. K., HaRboe, M., AND KunKel, H. G. (1963) Vox Sang., 8, 133 (Anti-gammaglobulin factors in human sera revealed by enzymatic splitting of anti-Rh antibodies)

RoparTz, C., Rivat, L., AND Rivat, C. (1971) 'Human anti-human globulin with idiotypic specificities in human anti-human gammaglobulins', In 'Human Anti-Human Globulins', ed. R. Grubb and G. Samuelson, p. 23. Pergamon Press, Oxford

Rose, H. M., Ragan, C., Pearce, E., and Lipman, M. O. (1948) Proc. Soc. exp. Biol. (N. Y.), 68, 1 (Differential agglutination of normal and sensitized sheep erythrocytes by sera of patients with RA)

Seward, C. W., AND OsterLand, C. K. (1973) J. Lab. clin. Med., 81, 230 (The pattern of anti-immunoglobulin activities in serum, pleural, and synovial fluids)

- PARKer, L. P., AND Osterland, C. K. (1972) Arthr. and Rheum., 15, 453 (Milgrom-type anti-antibody in matched serum and pleural or synovial fluids)

,,---1 (1974) J. Lab. clin. Med., 83, 104 (Anti-antibody and other anti-globulin specificities in nonrheumatoid and rheumatoid effusion fluids and matched sera)

ToRrigianI, G., AND RoITt, I. M. (1967) Ann. rheum. Dis., 26, 334 (Antiglobulin factors in sera from patients with rheumatoid arthritis and normal subjects)

Vaughan, J. H. (1963) Arthr. and Rheum., 6, 446 (Specificity of rheumatoid factor with gammaglobulin of different species)

WALLER, M. (1969) Ann. N.Y. Acad. Sci., 168, 5 (Methods of measurement of rheumatoid factor)

- and Vaughan, J. H. (1956) Proc. Soc. exp. Biol. (N.Y.), 92, 198 (Use of anti-Rh sera for demonstrating agglutination activating factor in rheumatoid arthritis)

Williams, R. C., AND KunKel, H. G. (1965) Proc. Soc. exp. Biol. (N.Y.), 124, 860 (Observations on anti-gammaglobulin factors in human sera and antibodies against autologous gammaglobulins produced in rabbits) 